\title{
Spastic Paraplegia 11
}

National Cancer Institute

\section{Source}

National Cancer Institute. Spastic Paraplegia 11. NCI Thesaurus. Code C148317.

An autosomal recessive condition caused by mutation(s) in the SPG11 gene, encoding spatacsin. It is a complicated sub-type of hereditary spastic paraplegia that has varying neurologic manifestations in addition to spasticity. 